\title{
GAMBARAN TINGKAT KECEMASAN IBU HAMIL DALAM PEMERIKSAAN KEHAMILAN DI PMB ISTRI UTAMI SELAMA PANDEMI
}

Sri Subiyatun, Esitra Herfanda,

\author{
Esitra_herfanda@unisayogya.ac.id, 085643234006
}

\begin{abstract}
ABSTRAK
Latar Belakang: Angka kematian ibu (AKI) dan angka kematian Bayi (AKB) merupakan indikator atau tolok ukur dalam bidang kesehatan. Kualitas pelayanan Kesehatan Ibu dan Anak (KIA) adalah salah satu faktor yang sangat mempengaruhi terjadinya kematian ibu maupun bayi. Kesehatan ibu hamil pada era pandemi Covid-19 ini harus jadi skala prioritas bagi dunia medis saat ini. Mengapa tidak, generasi penerus bangsa ada sama mereka dan mereka harus kita rawat (kelola) dengan baik agar terhindar dari hal-hal yang tidak kita inginkan. Tujuan: Mengetahui gambaran tingkat kecemasan ibu hamil dalam melakukan anc di PMB Istri Utami. Metode : Desain penelitian ini adalah deskriptif kuantitatif. Teknik sampling adalah purposive sampling, besar sampel 60 responden. Penelitian ini menggunakan kuesioner dengan google form sebagai alat ukur dan analisa data menggunakan univariat.
\end{abstract}

\section{Kata kunci : ANC, kehamilan, kecemasan}

\section{ABSTRACT}

Background: Maternal mortality rate (MMR) and infant mortality rate (IMR) are indicators or benchmarks in the health sector. The quality of Maternal and Child Health (MCH) services is one of the factors that greatly influences the occurrence of maternal and infant mortality. The health of pregnant women in the era of the Covid-19 pandemic must be a priority for the medical world today. Why not, the next generation of the nation is with them and we have to take care of them (manage) well to avoid things that we don't want Objective: To know the description of the level of anxiety of pregnant women in doing anc at PMB Istri Utami. Methods: The design of this research is descriptive quantitative. The sampling technique is purposive sampling, with a sample size of 60 respondents. This study uses a questionnaire with google form as a measuring tool and data analysis using univariate.

Keywords : ANC, pregnancy, anxiety

\section{PENDAHULUAN}

Angka kematian ibu (AKI) dan angka kematian Bayi (AKB) merupakan indikator atau tolok ukur dalam bidang kesehatan. Kualitas pelayanan Kesehatan Ibu dan Anak (KIA) adalah salah satu faktor yang sangat mempengaruhi terjadinya kematian ibu maupun bayi. Bagian yang tidak terpisahkan dalam pelayanan KIA adalah pemanfaatan buku KIA. Buku KIA saat ini belum dimanfaatkan secara optimal. Keberhasilan penggunaan buku KIA hanya terjadi apabila ibu, suami, keluarga aktif membaca, mempelajari, memahami secara bertahap isi buku KIA, dan menerapkan dalam kehidupan sehari-hari (Kemenkes 2015). 
Program Kesehatan Ibu dan Anak

(KIA) adalah merupakan salah satu prioritas utama pembangunan kesehatan di Indonesia. Program ini bertanggung jawab terhadap pelayanan kesehatan bagi ibu hamil, ibu melahirkan, bayi dan neonatal. Salah satu tujuan ini adalah menurunkan kematian dan kejadian sakit pada ibu dan anak melalui peningkatan mutu pelayanan dan menjaga kesinambungan pelayanan kesehatan ibu dan perinatal di tingkat pelayanan dasar dan pelayanan rujukan primer (Sistiarani C, 2012). Kecemasan adalah kekhawatiran atau ketegangan yang tidak jelas, perasaan tidak berdaya dan tidak pasti serta tidak memiliki objek yang spesifik, yang dialami secara subjektif dan dikomunikasikan secara interpersonal. Kesehatan ibu hamil pada era pandemi Covid-19 ini harus jadi skala prioritas bagi dunia medis saat ini. Mengapa tidak, generasi penerus bangsa ada sama mereka dan mereka harus kita rawat (kelola) dengan baik agar terhindar dari hal -hal yang tidak kita inginkan. Bagaimana kondisi ibu hamil pada era pandemi Covid19 ini menjadi sebuah penelitian khusus yang sangat menarik bagi kami dan kami paparkan di bawah ini sebagai tanggung jawab kami memberikan literasi dan edukasi kesehatan (Leo, 2020). Menurut Perhimpunan Dokter Spesialis Kedokteran Jiwa Indonesia (PDSKJI) sebanyak 64,3 persen dari 1.522 orang responden memiliki masalah psikologis cemas atau depresi setelah melakukan periksa mandiri via daring terkait kesehatan jiwa dampak dari pandemi COVID-19. Dari 1.522 responden tersebut paling banyak adalah perempuan 76,1 persen dengan usia minimal 14 tahun dan maksimal 71 tahun. Pengetahuan ibu hamil terhadap tanda-tanda persalinan sangatlah penting, karena dengan mengetahui tanda-tanda persalinan dapat diketahui bahwa persalinannya sudah dekat dan siap dalam persalinan sehingga ibu dan keluarga pun dapat lebih cepat ke rumah sakit atau ke klinik bersalin (Suririnah, 2004) diperkirakan sebanyak $90 \%$ kematian ibu terjadi pada saat sekitar persalinan, dan 95\% penyebab kematian adalah komplikasi obstetri yang sering tidak diperkirakan sebelumnya seperti perdarahan, infeksi, eklamsia, persalinan lama dan abortus komplikasi abortus. Kebijaksanaan departemen kesehatan untuk mempercepat penurunan Angka Kematian Ibu (AKI) adalah mengupayakan agar setiap persalinan ditolong atau minimal didampingi oleh bidan supaya mengurangi dua pertiga dari angka tingkat kematian bayi.

Antenatal Care (ANC ) adalah Pelayanan kesehatan yang diberikan tenaga kesehatan untuk ibu hamil selama masa kehamilan. Pelayanan tersebut merupakan bentuk upaya untuk menjaga kesehatan ibu pada masa kehamilan dan meminimalisasi risiko kejadian kesakitan dan kematian ibu (Farodis, 2012). Buku KIA diberikan pada kunjungan $\mathrm{K} 1$ atau kontak pertama ibu hamil dengan petugas kesehatan dan 
digunakan ibu mulai pada masa kehamilan,persalinan, nifas, sampai anak berusia 6 tahun. Setiap ibu hamil yang datang untuk ANC diwajibkan membawa buku KIA dan mempelajari isi dari buku tersebut dan diimplementasikan dalam kehidupan sehari- hari. Ibu hamil yang membaca buku KIA dapat menambah pengetahuan tentang perawatan kehamilan. Apabila ibu hamil mempunyai pengetahuan baik terhadap kesehatan maka akan memahami pentingnya menjaga kesehatan dan memotivasi untuk diaplikasikan dalam kehidupan sehari-hari.

Saat ini, layanan kesehatan ibu tidak terlepas terkena dampak baik secara akses maupun kualitas dikarenakan merebaknya Coronavirus disease 2019 (COVID-19) yang merupakan penyakit yang disebabkan oleh virus Severe Acute Respiratory Syndrome Coronavirus-2 (SARS- COV2). Pada tanggal 11 Maret 2020 WHO mendeklarasikan bahwa COVID-19 merupakan pandemi di dunia. Kasus COVID-19 pertama kali dilaporkan di Indonesia pada tanggal 2 Maret 2020, yang kemudian berkembang ke hampir seluruh provinsi di Indonesia, termasuk di Daerah Istimewa Yogyakarta (DIY).

\section{BAHAN DAN METODE}

Rancangan penelitian yang digunakan bersifat deskriptif kuantitatif. Deskriptif adalah penelitian yang diarahkan untuk menggambarkan suatu keadaan di dalam masyarakat. Sedangkan kuantitatif adalah data yang berhubungan dengan angka, baik yang diperoleh dari pengukuran maupun nilai dari suatu data. Pada penelitian ini mendeskripsikan tingkat kecemasan ibu hamil dalam pemeriksaan ANC selama masa pandemi. Teknik yang digunakan dalam penelitian ini adalah purposive sampling dimana teknik pengambilan sampel didasarkan pada suatu pertimbangan tertentu, yang dibuat oleh peneliti sendiri, berdasarkan ciri atau sifat populasi yang sudah diketahui sebelumnya (Notoatmodjo, 2012). Kriteria Inklusi meliputi: semua ibu hamil yang melakukan pemeriksaan kehamilan, ibu hamil yang mempunyai buku KIA, ibu hamil bersedia menjadi responden. Kriteria eksklusi penelitian ibu hamil yang tidak sedang melakukan kunjungan saat penelitian. Instrumen penelitian ini adalah alat-alat yang digunakan untuk pengumpulan data (Notoatmodjo, 2012). Instrumen penelitian yang digunakan adalah kuesioner tertutup. Kuesioner tertutup yaitu kuesioner terstruktur yang dibuat sedemikian rupa sehingga responden hanya cukup memilih atau menjawab jawaban yang sudah ada (Arikunto, 2010). Metode pengumpulan data menurut Riwidikdo (2009), merupakan kegiatan penelitian untuk mengumpulkan data. Untuk data penelitian ini menggunakan data primer diperoleh langsung dari sumbernya. Pengumpulan data pada penelitian ini menggunakan kuesioner atau daftar pernyataan yang dibagikan kepada responden melaui google 
form yang sebelumnya dijelaskan terlebih dahulu maksud, tujuan, dan cara pengisian google form.

\section{HASIL}

Tabel 1. Karakteristik berdasarkan Usia Ibu

\begin{tabular}{ccc}
\hline Umur Ibu & Frequency & Percent \\
\hline $21-25$ th & 14 & 40,0 \\
$26-28$ th & 7 & 20,0 \\
$29-32$ th & 7 & 20,0 \\
$33-35$ th & 2 & 5,7 \\
$36-38$ th & 3 & 8,6 \\
$39-42$ th & 2 & 5,7 \\
\hline
\end{tabular}

Berdasarkan tabel 1 dapat dijelaskan bahwa umur responden pada penelitian terbanyak ada di usia 21-25 tahun sebanyak $40 \%$ dan paling sedikit ada di usia 39-42 tahun sebanyak 5,7\%. Mayoritas usia ibu masih dalam usia ideal untuk hamil. Dalam kurun reproduksi sehat dikenal bahwa usia aman untuk kehamilan dan persalinan adalah 20-30 tahun. Usia seorang wanita pada saat hamil sebaiknya tidak terlalu muda dan tidak terlalu tua. Umur yang kurang dari 20 tahun atau lebih dari 35 tahun, berisiko tinggi untuk melahirkan. Kesiapan seorang perempuan untuk hamil harus siap fisik, emosi, psikologi, sosial dan ekonomi (Ruswana, 2006).

Tabel 2. Karakteristik berdasarkan Usia Ibu

\begin{tabular}{lrc}
\hline Trimester & Frequency & Percent \\
\hline TM1 & 9 & 25,7 \\
TM2 & 18 & 51,4 \\
TM3 & 8 & 22,9 \\
\hline
\end{tabular}

\begin{tabular}{rrrr} 
Berdasarkan & tabel & 2 dapat \\
dijelaskan & bahwa & umur & kehamilan \\
\hline
\end{tabular}

responden pada penelitian terbanyak ada di trimester kedua sebanyak $51,4 \%$, trimester $125,7 \%$ dan trimester ketiga sebanyak $22,9 \%$.

Tabel 3. Karakteristik berdasarkan Pendidikan Ibu

\begin{tabular}{lrr} 
Pendidikan & Frequency & Percent \\
\hline SMP & 6 & 17,1 \\
SMA & 16 & 45,7 \\
PT & 13 & 37,1 \\
\hline
\end{tabular}

Berdasarkan tabel 3 dapat dijelaskan bahwa pendidikan respondennya dari sisi mayoritas adalah lulusan SMA sebanyak $45,7 \%$ yang artinya dari sisi pengetahuan masih bisa menerima dan bisa mencari jika memerlukan informasi mengenai kehamilan.

Tabel 4. Karakteristik berdasarkan Pekerjaan Ibu

\begin{tabular}{lcr}
\hline Pekerjaan & Frequency & Percent \\
\hline IRT & 20 & 57,1 \\
Swasta & 10 & 28,6 \\
& & \\
Buruh / Wiraswasta & 5 & 14,3 \\
\hline
\end{tabular}

Berdasarkan tabel 4 dapat dijelaskan bahwa pekerjaan ibu sebagai IRT sebanyak $57,1 \%$, pegawai swasta $28,6 \%$ dan buru/wiraswasta sebanyak $14,3 \%$.

\section{Tabel 5. Kecemasan Ibu}

\begin{tabular}{lcc}
\hline Kecemasan & Frequency & Percent \\
\hline Tidak ada Kecemasan & 0 & 0 \\
Kecemasan Ringan & 0 & 0 \\
Kecemasan Sedang & 4 & 11,4 \\
Kecemasan Berat & 4 & 11,4 \\
Kecemasan Berat Sekali & 27 & 77,1 \\
\hline
\end{tabular}

Berdasarkan tabel 5 dapat dijelaskan bahwa kecemasan yang dialami 
ibu hamil selama pemeriksaan kehamilan di masa pandemi dengan kecemasan ringan $11,4 \%$, kecemasan berat $11,4 \%$, dan kecemasan berat sekali $77,1 \%$. Hal ini menunjukkan bahwa tingkat kecemasan ataupun kekhawatiran ibu hamil pada masa pandemi ini cukup memprihatinkan. Kecemasan ini dimungkinkan akibat dari beberapa faktor. Faktor-faktor yang dapat mencetuskan stres pada ibu hamil diantaranya rasa ketidaknyamanan selama kehamilan, pekerjaan, kekhawatiran pada proses persalinan, perubahan hormon serta kondisi bayi. Hasil studi melaporkan bahwa berdasarkan keterangan yang diperoleh dari ibu hamil dengan stres, berbagai macam masalah yang mereka alami meliputi permasalahan ekonomi, keluarga, pekerjaan, serta rasa cemas terhadap kehamilan maupun persalinan (Taslim, Kundre and Masi, 2016).

Tabel 6. Tabel Silang Umur ibu berdasarkan kecemasan

\begin{tabular}{|c|c|c|c|c|c|c|c|c|c|c|}
\hline \multirow{3}{*}{ Umur tbu } & \multicolumn{10}{|c|}{ Kecemasan } \\
\hline & \multicolumn{2}{|c|}{$\begin{array}{l}\text { Tidak Ada } \\
\text { Kecemasan }\end{array}$} & \multicolumn{2}{|c|}{$\begin{array}{l}\text { Kecemasan } \\
\text { Ringan }\end{array}$} & \multicolumn{2}{|c|}{$\begin{array}{l}\text { Kecemasan } \\
\text { Sedang }\end{array}$} & \multicolumn{2}{|c|}{$\begin{array}{c}\text { Kecemasan } \\
\text { Berat }\end{array}$} & \multicolumn{2}{|c|}{$\begin{array}{c}\text { Kecemasan Bera } \\
\text { Sekali }\end{array}$} \\
\hline & $\mathrm{N}$ & $\%$ & N & $\%$ & $\mathrm{~N}$ & $\%$ & $\mathrm{~N}$ & $\%$ & N & $\%$ \\
\hline 21.25 th & 0 & 0 & 0 & 0 & 0 & 0 & 1 & 7 & 13 & 93 \\
\hline $26-28$ th & 0 & 0 & 0 & 0 & L & 29 & 0 & 0 & 5 & 71 \\
\hline $29 \cdot 32$ th & 0 & 0 & 0 & 0 & & 0 & 2 & 29 & 5 & 71 \\
\hline $33-35$ th & 0 & 0 & 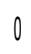 & 0 & 1 & 50 & 0 & 0 & 1 & 50 \\
\hline $36-38$ th & 0 & 0 & 0 & 0 & 1 & 33 & 0 & 0 & 2 & 67 \\
\hline 39.42 th & 0 & 0 & 0 & 0 & 0 & 0 & 1 & 50 & 1 & 50 \\
\hline
\end{tabular}

Berdasarkan tabel 6 dapat dijelaskan bahwa semua responden mengalami kecemasan saat melakukan pemeriksaan kehamilan di masa pandemi ini. Dari 35 orang responden sebanyak 2 orang responden berusia 26-28 tahun mengalami kecemasan sedang dan 5 orang mengalami kecemasan berat sekali. Sedangkan pada usia 29-32 tahun sebanyak 2 responden mengalami kecemasan berat dan 5 orang mengalami kecemasan berat sekali. Pada usia 33-35 tahun terdapat 1 responden dengan kecemasan sedang dan 1 responden mengalami kecemasan berat sekali. Pada usia 36-38 tahun sebanyak 1 responden mengalami kecemasan sedang dan 2 responden mengalami kecemasan berat sekali. Pada usia 39-42 tahun terdapat 1 responden yang mengalami kecemasan berat dan 1 responden mengalami kecemasan berat sekali.

Tabel 7. Tabel Silang Umur kehamilan ibu berdasarkan kecemasan

\begin{tabular}{|c|c|c|c|c|c|c|c|c|c|c|}
\hline \multirow{3}{*}{$\begin{array}{c}\text { Trimeste } \\
r\end{array}$} & \multicolumn{10}{|c|}{ Kecemasan } \\
\hline & \multicolumn{2}{|c|}{$\begin{array}{l}\text { Tidak Ada } \\
\text { Kecemasan }\end{array}$} & \multicolumn{2}{|c|}{$\begin{array}{l}\text { Kecemasan } \\
\text { Ringan }\end{array}$} & \multicolumn{2}{|c|}{$\begin{array}{c}\text { Kecemasan } \\
\text { Sedang }\end{array}$} & \multicolumn{2}{|c|}{$\begin{array}{c}\text { Kecemasan } \\
\text { Berat }\end{array}$} & \multicolumn{2}{|c|}{$\begin{array}{c}\text { Kecemasan Berat } \\
\text { Sekali }\end{array}$} \\
\hline & $N$ & $\%$ & $N$ & $\%$ & $\mathrm{~N}$ & $\%$ & N & $\%$ & $N$ & $\%$ \\
\hline TM1 & 0 & 0 & 0 & 0 & 1 & 11 & ก & 0 & 8 & 89 \\
\hline TM2 & 0 & 0 & 0 & 0 & 2 & 11 & 3 & 17 & 13 & 72 \\
\hline TM3 & 0 & 0 & 0 & 0 & 1 & 13 & 1 & 13 & 6 & 75 \\
\hline
\end{tabular}

Berdasarkan tabel 7 dapat dijelaskan bahwa responden dengan usia kehamilan trimester 1 sebanyak 1 orang mengalami kecemasan sedang dan 8 responden mengalami kecemasan berat sekali. Pada usia kehamilan trimester 2 sebanyak 2 responden mengalami kecemasan sedang dan 3 responden mengalami kecemasan berat dan 13 responden mengalami kecemasan berat sekali. Pada usia kehamilan trimester 3 terdapat 1 responden mengalami kecemasan 
sedang, 1 responden mengalami kecemsan berat dan 6 responden mengalami kecemasan berat sekali.

Tabel 8. Tabel Silang pendidikan ibu berdasarkan kecemasan

\begin{tabular}{|c|c|c|c|c|c|c|c|c|c|c|}
\hline \multirow{3}{*}{ Pendidikan } & \multicolumn{10}{|c|}{ Kecemasan } \\
\hline & \multicolumn{2}{|c|}{$\begin{array}{l}\text { Tidak Ada } \\
\text { Kecemasan }\end{array}$} & \multicolumn{2}{|c|}{$\begin{array}{c}\text { Kecemasan } \\
\text { Ringan }\end{array}$} & \multicolumn{2}{|c|}{$\begin{array}{c}\text { Kecemasann } \\
\text { Sedang }\end{array}$} & \multicolumn{2}{|c|}{$\begin{array}{c}\text { Kecemasan } \\
\text { Berat }\end{array}$} & \multicolumn{2}{|c|}{$\begin{array}{c}\text { Kecemasan Berat } \\
\text { Sekali }\end{array}$} \\
\hline & $\mathrm{N}$ & $\%$ & $\mathbb{N}$ & $\%$ & N & $\%$ & N & $\%$ & N & $\%$ \\
\hline SMP & 0 & 0 & 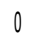 & 0 & 2 & 33 & 1 & 17 & 3 & 50 \\
\hline SMA & 0 & 0 & 0 & 0 & 1 & 6 & 2 & 13 & 12 & 81 \\
\hline PT & 0 & 0 & & 0 & & 8 & & & & 85 \\
\hline
\end{tabular}

Berdasarkan tabel 8 dapat dijelaskan bahwa responden dengan tingkat pendidikan terakhir SMP mengalami kecemasan sedang sebanyak 2 responden, kecemasan berat 1 responden dan kecemasan berat sekali 3 responden. Pada tingkat pendidikan SMA mengalami kecemasan sedang sebanyak 2 responden, kecemasan berat 1 responden dan kecemasan berat sekali 13 responden. Pada tingkat pendidikan PT mengalami kecemasan sedang sebanyak 1 responden, kecemasan berat 1 responden dan kecemasan berat sekali 11 responden. Ratarata pada pendidikan SMA memiliki tingkat kecemasan berat sekali terbanyak.

Tabel 9. Tabel Silang pekerjaan ibu berdasarkan kecemasan

\begin{tabular}{lccccccccccc}
\hline & \multicolumn{1}{c}{$\begin{array}{c}\text { Kecemasan } \\
\text { Pekerjaan }\end{array}$} & $\begin{array}{c}\text { Tidak Ada } \\
\text { Kecemasan }\end{array}$ & \multicolumn{2}{c}{$\begin{array}{c}\text { Kecemasan } \\
\text { Ringan }\end{array}$} & $\begin{array}{c}\text { Kecemasan } \\
\text { Sedang }\end{array}$ & \multicolumn{2}{c}{$\begin{array}{c}\text { Kecemasan } \\
\text { Berat }\end{array}$} & \multicolumn{2}{c}{$\begin{array}{c}\text { Kecemasan Berat } \\
\text { Sekali }\end{array}$} \\
& $\mathrm{N}$ & $\%$ & $\mathrm{~N}$ & $\%$ & $\mathrm{~N}$ & $\%$ & $\mathrm{~N}$ & $\%$ & $\mathrm{~N}$ & $\%$ \\
\hline IRT & 0 & 0 & 0 & 0 & 1 & 5 & 2 & 10 & 17 & 85 \\
Swasta & 0 & 0 & 0 & 0 & 1 & 10 & 0 & 0 & 9 & 90 \\
Buruh/ & & & & & & & & & & \\
Wiraswast & & & & & & & & & & \\
a & 0 & 0 & 0 & 0 & 2 & 40 & 2 & 40 & 1 & 20 \\
\hline
\end{tabular}

Berdasarkan tabel 9 dapat

dijelaskan bahwa responden dengan pekerjaan sebagai ibu rumah tangga mengalami kecemasan sedang sebanyak 1 responden, kecemasan berat 2 responden dan kecemasan berat sekali 17 responden. Pada pekerjaan swasta yang mengalami kecemasan sedang sebanyak 1 responden dan kecemasan berat sekali 9 responden. Pada pekerjaan buru ataupun wiraswasta yang mengalami kecemasan sedang sebanyak 2 responden, kecemasan berat 2 responden dan kecemasan berat sekali 1 responden. Rata-rata dengan pekerjaan sebagai ibu rumah tangga tingkat kecemasan berat sekali terbanyak.

\section{PEMBAHASAN}

Berdasarkan hasil analisis data pada penelitian ini sebagian besar ibu hamil mengalami kecemasan berat sekali pada saat melakukan pemeriksaan kehamilan di masa pandemi sebanyak 77,1\%. Dari laporan Organisasi Kesehatan Dunia menyatakan bahwa sekitar $10 \%$ wanita hamil mengalami gangguan mental, terutama depresi. Di dalam negara berkembang, prevalensinya merata lebih tinggi, mencapai $15,6 \%$ selama kehamilan dan $19,8 \%$ setelah melahirkan. Sesuatu yang tidak terduga atau tidak diketahui akan membuat kecemasan ini meningkat. Kecemasan ini sebagian disumbangkan oleh perubahan fisiologis pada trimester 1 , 2, dan 3. dipicu oleh perubahan hormonal yang dialami oleh ibu hamil, yang masih menimbulkan emosi perubahan dan 
perubahan suasana hati. Dukungan dari suami dan keluarga sangat dibutuhkan selama masa kehamilan. Dukungan sosial dapat mengurangi efek stres prenatal dan telah ditunjukkan untuk mengurangi dampak kecemasan prenatal dan gejala depresi pada ibu dan bayi sistem respon stres. Aktivitas fisik juga berhubungan dengan penurunan depresi dan kecemasan gejala pada ibu hamil. Kecemasan yang berlebihan pada wanita hamil dapat menyebabkan patologis kecemasan yang dapat menyebabkan komplikasi untuk ibu dan janin. Kehadiran ini pandemi coronavirus meningkatkan kecemasan dan memicu rasa takut yang berlebihan di kalangan ibu hamil karena kurangnya pengetahuan dan keterpaparan terhadap informasi yang salah atau disinformasi mengenai pandemi.

Penelitian yang dilakukan oleh Durankus mengenai efek dari pandemi covid 19 ini bisa meningkatkan depresi dan kecemasan pada ibu hamil baik tentang dirinya maupun bayinya. Penelitian ini menekankan juga pada pemberian konseling pada ibu hamil untuk mencegah dari kecemasan yang berakibat hingga depresi. Ekspresi emosional yang sering diperlihatkan oleh ibu hamil bisa menjadi tanda bahwa seorang ibu hamil memerlukan tempat ataupun informasi yang menenangkan dan bisa didapatkan dari tenaga kesehatan.

Pemeriksaan kehamilan yang idealnya dilakukan minimal $4 \mathrm{x}$ selama kehamilan sekarang harus berkurang karena pandemi. Walaupun untuk konsultasi dan pemeriksaan sekarang menggunakan telemedicine dimana pasien bisa bertemu dengan dokter ataupun bidan menggunakan media digital seperti zoom, google meet ataupun video call, akan tetapi kepuasan dari ibu hamil juga kurang dikarenakan pemeriksaan secara fisik dilakukan dengan seminimal mungkin.

Penyebab tingkat kecemasan ibu hamil tinggi diantaranya ibu hamil yang melakukan pemeriksaan kehamilan merasa takut jika harus periksa di rumah sakit karena takut tertular dan akan menyebabkan bayinya meninggal, sementara perasaan cemas ketika berada di banyak orang dan tanpa menggunakan masker, bergejala batuk ataupun pilek sehingga ada kecemasan tersendiri. Beberapa ibu hamil memilih dan memilah tempat untuk bersalin di amsa pandemi ini. Praktik bidan mandiri menjadi salah satu pilihan yang banyak dipilih sebagai tempat pemeriksaan kehamilan hingga persalinan nantinya.

Perempuan hamil kurang dari 20 tahun dapat merugikan kesehatan ibu maupun pertumbuhan dan perkembangan janin karena belum matangnya alat reproduksi untuk hamil. Penyulit pada kehamilan remaja. Sebagian besar wanita yang berusia di atas 35 tahun mengalami kehamilan yang sehat dan dapat melahirkan bayi yang sehat pula. Tetapi beberapa penelitian menyatakan semakin matang usia ibu dihadapkan pada kemungkinan 
terjadinya beberapa risiko tertentu,

termasuk risiko kehamilan.

\section{KESIMPULAN DAN SARAN}

Kesimpulan dalam penelitian yaitu peemriksaan ANC di masa pandemic ini menyebabkan kecemasan tersendiri pada ibu hamil.

\section{DAFTAR PUSTAKA}

1. Arikunto, 2013. Prosedur Penelitian Suatu Pendekatan Praktek. Jakarta: Rineka Cipta.

2. Azwar, Saifudin. 2011. Penyusunan Skala Psikologi. Yogyakarta: Pustaka Pelajar. Budiman, dan Riyanto. (2013). Kapita Salekta Kuesioner : Pengetahuan dan Sikap Dalam Penelitian Kesehatan. Jakarta: Salemba Medika.

3. Boeling, et al. (2020). MFM Guidance for COVID-19. American Journal of Obstetrics \& Gynecology MFM, 2020.100106.

4. Buku Kesehatan ibu dan Anak Departemen Kesehatan Republik Indonesia. 2015. Bakti Husada Kementrian Kesehatan Republik Indonesia.

5. Colti, Sistiarini., Gamelia, Elviera., Sari, Dyah. (2014). Fungsi Pemanfaatan Buku KIA terhadap Pengetahuan Kesehatan Ibu dan Anak pada Ibu. Jurnal Kesmas National Public Health Journal Vo. 8 No. 8.

6. Dinkes Sleman, 2015. Profil Kesehatan Kabupaten Sleman Tahun 2014. Yogyakarta: Dinkes Sleman.

7. Diani LPP, Susilawati, KPA. Pengaruh dukungan suami terhadap istri yang mengalami kecemasan pada kehamilan trimester ketiga di Kabupaten Gianyar. Jurnal Psikologi Udayana. 2013;1(1):111.

8. Ernoviana, M, H. 2006. Pemanfaatan Buku Kesehatan Ibu dan Anak di Dinas Kesehatan Kota Sawahlunto. Yogyakarata. Unuversitas Gadjah Mada.

9. Farodis, Zian. 2012. Panduan Lengkap Menejemen Kebidanan. Yogyakarta: D- Medika.

10. Green, Lowrence., Kreuter, W. 2005. Helath Promotion Planning: An Educational and Ecological Approach. 4th Edition New York: McGraw Hill.

11. Guille C, Newman RB, editors. Clinics review article perinatal mental health; obstetrics and gynecology clinics of North America. Amsetrdam: Elsevier; 2018

12. Hani, U, dkk. 2011.Asuhan Kebidanan Pada Kehamilan Fisilogis. Jakarta: Salemba Medika.

13. Mori, Rintaro., Yonemato, Naohiri., Noma, Hisashi et al. 2015. The Maternal and Child Helat (MCH) Handbook in Mongolia: A Cluster- Randomized, Controlled Trial. Journal.pone DOI: 10.1371 .

14. Nzioki, Japhet., Onyango, Rosebella., Ombaka, James. 2015. Socio demographic Factors Influencing Maternal and Child Mental Helat Service Utilization in Mwingi: A rural Semi-Arid District in Kenya. American Journal of Public Healt Reseach Vol. 3 No. 1, 21-30 